\title{
Contraceptive Use Among the Poor in Indonesia
}

By Juan Schoemaker

Juan Schoemaker is senior research and evaluation officer, Johns Hopkins Bloomberg School of Public Health/Center

for Communication Programs, Baltimore, MD, USA.
CONTEXT: Indonesia has experienced a dramatic increase in contraceptive use and an equally dramatic fertility decline over the last 30 years. Yet recent reductions in family planning funding, program decentralization and the diminishing role of the public sector as a service provider may lead to lower use among poor women.

METHODS: The data for analysis were drawn from the 2002-2003 Indonesia Demographic and Health Survey. Bivariate techniques were used to compare overall contraceptive use, reliance on specific methods, source of supplies and reasons for nonuse of contraceptives between poor and better-off women. Multivariate regression assessed the association between use of a modern method and selected social, demographic and attitudinal characteristics.

RESULTS: Better-off women wanted significantly fewer children than did moderately or extremely poor women (2.8 vs. 3.0-3.4), were more likely to approve of family planning (93\% vs. 87-91\%) and were more likely to believe their spouses approved (91\% vs. 80-87\%). Better-off women and moderately poor women had higher odds of using modern contraceptives than did extremely poor women (odds ratios, 1.6 and 1.4, respectively). Compared with women who gave a nonnumeric response, those who wanted two or fewer children had higher odds of using a modern method (2.0). The odds were also higher among women who lived in a district in which the mean ideal number of children was below the national median (1.5).

CONCLUSION: Governmental efforts to increase contraceptive use among poor women need to focus on changing attitudes toward smaller family sizes and family planning.

International Family Planning Perspectives, 2005, 31(3):106-114
Indonesia's family planning program has been very successful. Since its creation in 1970, the National Family Planning Coordinating Board (Badan Koordinasi Keluarga Berencana Nasional-BKKBN) has spearheaded the effort to make modern contraceptive methods accessible to Indonesian families and to promote smaller family norms. ${ }^{1}$ The program contributed to a rapid increase in the contraceptive prevalence rate (CPR), from 26\% in 1976 to $60 \%$ in 2002, and a drop in the total fertility rate (TFR), from 5.6 to 2.6 lifetime births per woman, during the same period. $* 2$

The Indonesian family planning program has been heavily dependent on government subsidies and contributions from foreign donors. Efforts to transfer the costs of family planning from the government to clients started in 1987, under the KB-Mandiri (family planning self-reliance) program, which was credited with increasing the proportion of women using private sources from $12 \%$ in 1987 to $22 \%$ in $1991 .{ }^{3}$ Despite this achievement, program managers and researchers were concerned that poor couples who could

*The Indonesia Fertility Survey, on which the 1976 figures are based, covered the islands of Java and Bali only, whereas the Indonesia Demographic and Health Survey of 2002-2003 covered the entire country. Making these figures comparable by confining the analysis to Java and Bali reveals even steeper changes: For these islands, the CPR increased from $26 \%$ to $63 \%$ and the TFR declined from 5.6 to 2.4 lifetime births per woman between 1976 and 2002. not afford to continue using their chosen method as market prices rose might not switch to an alternative method, causing an overall decline in use. ${ }^{4}$

The 1997 Asian economic crisis hit Indonesia particularly hard, leading to currency destabilization, a sharp increase in consumer prices, massive unemployment and a substantial increase in the number of people living in poverty. ${ }^{5}$ One effect of this crisis was that government funding for family planning declined substantially at a time when contraceptive prices were rising markedly.

However, the reduction in funding did not cause a drop in the CPR. A study based on the Indonesia Family Life Survey found no significant changes in the level of prevalence or the mix of contraceptive methods, ${ }^{6}$ and data from the Indonesia Demographic and Health Survey (IDHS) series suggest that as cost-free methods became less available in the public sector, women simply bought methods through the private sector.

The shift of users from the public to the private sector, already discernible in the early 1990s, continued through 2002, the last year for which data are available (Figure 1). The proportion of married women obtaining modern contraceptive methods from the private sector jumped from $22 \%$ to $63 \%$ between 1991 and 2002, while the proportion obtaining methods from the public sector fell from $51 \%$ to $28 \%$. The proportion using village delivery posts and health posts 
FIGURE 1. Percentage distribution of currently married women using modern contraceptives, by source, according to year

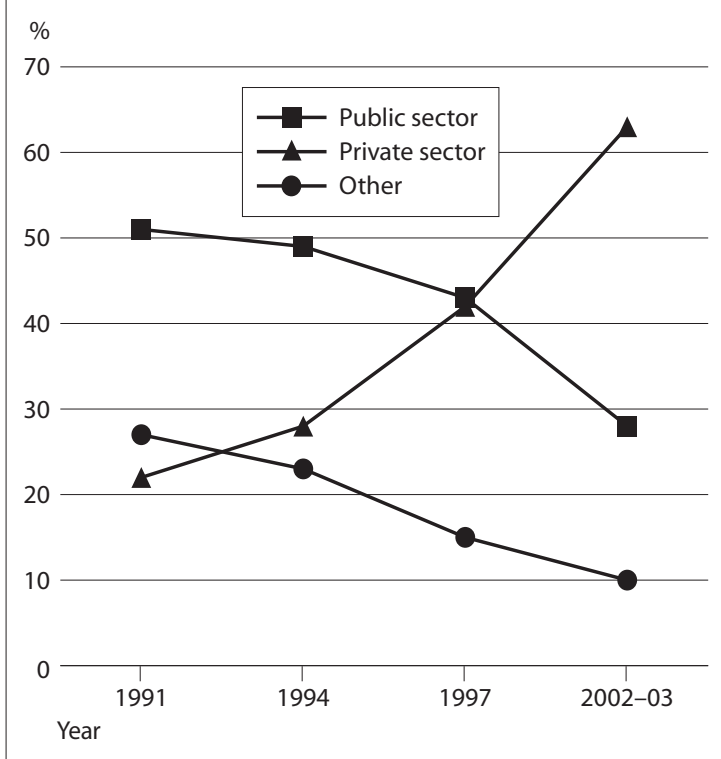

Notes: Source of contraception is defined as the last place a respondent obtained a contraceptive method. Private sector includes private midwives and other private medical and commercial providers.

supported by nongovernmental organizations (NGOs)shown by the "other" trend line in Figure 1-also dropped: Twenty-seven percent of married users relied on these sources in 1991, compared with only $10 \%$ in 2002 . This shift to the private sector gathered momentum during a period when both the cost of living and contraceptive prices doubled. ${ }^{7}$

Because women switched to the private sector as government subsidies shrank, the proportion using modern contraceptives did not decline between 1997 and 2002, but instead edged up slightly, from $55 \%$ to $57 \% .^{8}$ Thus, the drop in government subsidies apparently did not affect the general ability of the population as a whole to obtain contraceptives.

It is not clear, however, what effect reduced subsidies had on the poor. Historically, socioeconomic status and contraceptive use have been consistently and strongly associated in the demographic study of developing countries. Nevertheless, the explanation for this association has been subject to debate for decades. According to the "supplyside" school of thought, lower contraceptive use by lowincome populations is caused by financial constraints and geographic isolation that create greater difficulties for poor couples in obtaining contraceptives. ${ }^{9}$ From the "demandside" viewpoint, however, poor women are less likely to use contraceptives because of sociocultural and attitudinal factors, such as considering children to be potential economic assets and attaching high value to large families. ${ }^{10}$

This study examines changes in the pattern of contraceptive use among poor Indonesian women in a climate of diminishing government subsidies, and assesses the extent to which these changes were caused by monetary constraints and by cultural and attitudinal factors.

\section{METHODS}

Data for analysis were drawn from the IDHS conducted between October 2002 and April 2003 among 29,483 evermarried women aged 15-49. All variables for analysis were constructed from those in the standardized IDHS data file.

Socioeconomic status represents a respondent's level of material wealth, based on the physical condition of her dwelling and the material possessions in the household. * Principal components analysis was used to calculate factor scores for selected household assets, such as electricity, television, water piped into the residence and household possessions. The resulting asset scores were standardized in relation to a normal distribution with a mean of zero and a standard deviation of one. A value of one was assigned to households that had a given asset and a value of zero to those that did not. The sum of these scores constituted the socioeconomic status index, which was attributed to all respondents living in a given household. ${ }^{11}$ The possession of durable goods constitutes a more stable indicator of a household's long-term welfare than do consumption indicators. Consumption is highly volatile and may rise and fall substantially along with seasonal variations and fluctuations in the economy, whereas the stream of benefits from durable possessions tends to be steadier. ${ }^{12}$

Socioeconomic status is included in the standard 2002-2003 IDHS data file as an ordinal variable broken into quintiles: lowest, lower middle, middle, upper middle and highest. Because this analysis focuses on women in the lowest quintile, described herein as "poor," I divided all respondents into deciles and designated the lowest decile as "extremely poor" and the second-lowest decile as "moderately poor"; women in the top eight deciles are referred to as being of higher socioeconomic status or simply as "better off."

The respondents were divided into two age-groups: 15-34 and 35-49. The first group included women at the peak of their reproductive cycle: They contributed $83 \%$ of overall fertility, the majority were fecund and they were more likely to be sexually active than women in the older age-group.

Survey data from numerous developing countries have consistently shown that a woman's contraceptive use is closely associated with her number of living children. This variable was divided into three categories: two or fewer children, three to four, and five or more. The lowest category represents fertility at replacement level or below, the standard that the Indonesian government has promoted for many years through its "Two Is Enough" campaign. Women with three or four children have moderately high fertility, and those with five or more have high fertility. The ideal number of children variable has three categories: women whose ideal number is two or fewer, those whose ideal is three or more, and those who responded with statements

*The government of Indonesia does not have a single official definition of what level of income or wealth constitutes "poverty." The Central Bureau of Statistics and BKKBN use different criteria, which produce significantly different estimates of the proportion of poor people in the general population. 


\begin{tabular}{|c|c|c|c|c|}
\hline Characteristic & All & $\begin{array}{l}\text { Extremely } \\
\text { poor }\end{array}$ & $\begin{array}{l}\text { Moderately } \\
\text { poor }\end{array}$ & $\begin{array}{l}\text { Better } \\
\text { off }\end{array}$ \\
\hline \multicolumn{5}{|l|}{ \% DISTRIBUTIONS } \\
\hline Education & $(\mathrm{N}=29,464)$ & $(\mathrm{N}=4,845)$ & $(\mathrm{N}=3,313)$ & $(\mathrm{N}=21,306)$ \\
\hline <complete primary & 27.9 & 47.6 & 42.2 & 23.6 \\
\hline Complete primary & 35.9 & 38.6 & 44.0 & 34.6 \\
\hline >complete primary & 36.2 & 13.8 & 13.8 & 41.8 \\
\hline \multicolumn{5}{|l|}{ Design-based $F=119.6, p<.001$} \\
\hline Residence & $(\mathrm{N}=29,483)$ & $(\mathrm{N}=4,846)$ & $(\mathrm{N}=3,316)$ & $(\mathrm{N}=21,321)$ \\
\hline Urban & 45.7 & 3.8 & 11.1 & 55.2 \\
\hline Rural & 54.3 & 96.2 & 88.9 & 44.8 \\
\hline \multicolumn{5}{|l|}{ Design-based $F=205.7, p<.001$} \\
\hline Total & 100.0 & 100.0 & 100.0 & 100.0 \\
\hline \multicolumn{5}{|l|}{ PERCENTAGES } \\
\hline Media exposure§ & $(\mathrm{N}=29,483)$ & $(\mathrm{N}=4,846)$ & $(\mathrm{N}=3,316)$ & $(\mathrm{N}=21,321)$ \\
\hline $\begin{array}{l}\text { Exposed to broadcast family planning } \\
\text { messages }\end{array}$ & 49.9 & 19.7 & $32.1 \dagger$ & $55.9+, \neq$ \\
\hline Has a radio & 58.6 & 24.8 & $38.3+$ & $64.2+, \neq$ \\
\hline Has a TV & 67.2 & 6.0 & $23.6 \dagger$ & $79.1+, \neq$ \\
\hline \multicolumn{5}{|l|}{ Contraceptive use among currently } \\
\hline Using modern contraceptive & 56.7 & 43.4 & $53.2 \dagger$ & $58.8+, \neq$ \\
\hline \multicolumn{5}{|l|}{ Has unmet need for modern family } \\
\hline planning & 12.2 & 19.1 & $12.4 \dagger$ & $11.4 \dagger$ \\
\hline \multicolumn{4}{|c|}{ Health care use among mothers with a live } & $(\mathrm{N}=9,314)$ \\
\hline Received tetanus vaccine prior to birth & & & & \\
\hline of last child & 72.4 & 52.6 & $61.5+$ & $76.6+, \neq$ \\
\hline \multicolumn{5}{|l|}{ Received antenatal care from health } \\
\hline professional during last pregnancy & 60.7 & 28.2 & $41.7 \dagger$ & $67.8+, \neq$ \\
\hline Delivered last child in health facility & 18.9 & 4.4 & $6.2 \dagger$ & $22.6+, \neq$ \\
\hline
\end{tabular}

†Differs significantly from the extremely poor at $\mathrm{p} \leq .01$. $\neq$ Differs significantly from the moderately poor at $\mathrm{p} \leq .01$. $\S N$ s for items within a panel may differ because women with missing data were excluded. Note: Extremely poor women were in the bottom decile as determined by socioeconomic measures, moderately poor women were in the next lowest decile and better-off women included the remaining eight deciles.

such as "It's up to God" and "It depends on my husband," or gave some other nonnumeric answer.

I used a district's mean ideal number of children as an indicator of the possible influence of social norms on childbearing in the respondents' environment. To remove any potential bias that respondents' own viewpoints may have on the estimation of their district means, I excluded a woman's own preference from these estimates. The median value for all districts' mean ideal number of children is 2.84 .

Exposure to family planning messages was included in the analysis because a growing body of research has shown that exposure to such messages is strongly associated with increased contraceptive use. ${ }^{13}$ Respondents who recalled having seen or heard a family planning message during the six months preceding the survey were considered to have been exposed to such messages. To assess message "dose," I classified respondents as not exposed, exposed to messages from only one source or exposed to messages from multiple sources.

A woman is protected against unwanted pregnancy only if she is using a modern contraceptive method; women who do not want to get pregnant and who are not using such methods, as well as those using traditional or folk methods, are considered to have an unmet need for family planning. The latter methods are considered ineffective because they do not provide reliable protection against unwanted pregnancy. ${ }^{14}$ The 2002-2003 Indonesia survey shows that method failure was the reason for method discontinuation for $29 \%$ of women using periodic abstinence and for $28 \%$ of women using withdrawal. ${ }^{15}$

Odds ratios from multivariate logistic regression analysis were calculated to assess associations between the use of modern contraceptive methods and various respondent characteristics. The two-tailed $z$ test for the logistic regression analysis and the design-based F statistic were used to determine statistical significance. The corrected $p$ value for $\mathrm{F}$ can be interpreted in the same way as the $\mathrm{p}$ value of the $\chi^{2}$ statistic, but it has the advantage of taking into account any survey design effects. Only differences at levels of $\mathrm{p} \leq .05$ were considered significant.

\section{RESULTS}

\section{Respondent Characteristics}

Almost half of extremely poor women (48\%) had not completed their primary education, compared with $42 \%$ of moderately poor women and $24 \%$ of those with higher socioeconomic status (Table 1). Only 14\% of extremely and moderately poor women had continued their education beyond primary school, whereas $42 \%$ of better-off women had done so. The vast majority of poor women-96\% of the extremely poor and $89 \%$ of the moderately poor-lived in rural areas. In contrast, just $45 \%$ of better-off women lived in rural areas.

Exposure to family planning messages through broadcast media was markedly lower among poor women. Only $20 \%$ of the extremely poor recalled having seen or heard a family planning message on either television or radio in the six months preceding the survey, compared with 32\% of the moderately poor and $56 \%$ of those who were better off. This difference is explained mainly by the disparity in ownership of televisions and radios: Only $6 \%$ of the extremely poor owned a television set, compared with $24 \%$ of the moderately poor and $79 \%$ of those with higher socioeconomic status. Similarly, only $25 \%$ of the extremely poor owned a radio, whereas $38 \%$ and $64 \%$ of the moderately poor and better-off women, respectively, had radios.

Forty-three percent of the poorest women used modern contraceptives, compared with 53\% of moderately poor and $59 \%$ of better-off women. Unmet need for modern family planning was highest among extremely poor women (19\%). The level of unmet need among moderately poor and better-off women was much lower (11\%-12\%).

Among women who had had a live birth during the five years preceding the survey, $53 \%$ of the extremely poor had used basic health services (represented by having received a tetanus vaccination prior to the birth of their last child), a significantly smaller proportion than that found among moderately poor or better-off women (62\% and $77 \%$, respectively). A similar pattern was found in the proportions of women 
who had received antenatal care from a health professional during their last pregnancy (28\%, 42\% and 68\%, respectively), and in the proportions who had delivered their last child at a health facility (4\%,6\% and 23\%, respectively).

In general, differences between poor and better-off women, as well as differences between extremely and moderately poor women, were larger for use of basic health services than for contraceptive use. This suggests that family planning programs are more accessible to poor people than other health services or that poor people have been more willing to use them. Moreover, the gap between the extremely poor and the moderately poor in contraceptive use is wider than the gap between the moderately poor and the better off. This suggests that barriers to the adoption and use of modern contraceptives-whether they relate to access or sociocultural factors-may be particularly difficult to overcome for the poorest Indonesian women.

\section{Method Mix}

Overall, almost three-quarters of currently married women using modern contraceptives relied on a short-term hormonal method (the pill or the injectable); the differences among socioeconomic categories were slight, but statistically significant (Table 2). About a quarter of all modern contraceptive users relied on a long-term method (the IUD, the implant or sterilization), and fewer than $2 \%$ used a barrier method. Because short-term hormonal methods require restocking of supplies, the widespread dependence on these methods means that a substantial proportion of users-especially those who are poor-are in a vulnerable position in terms of contraceptive security. Disruptions in the supply chain and periods of lack of disposable income could seriously impair their ability to prevent unwanted pregnancies.

When the contraceptive mix was expanded to include traditional methods (withdrawal, periodic abstinence and the lactational amenorrhea method), ${ }^{*}$ the proportion of use among extremely poor women accounted for by these methods was double that among moderately poor and better-off women ( $11 \%$ vs. $5 \%-6 \%$ ). The high proportion of extremely poor women relying on traditional methods may reflect an inability to pay for modern contraceptives. An initial assessment carried out in low-income quarters and among health providers serving them found a recurrent pattern of poor couples resorting to traditional methods when they were unable to obtain modern contraceptives. ${ }^{16}$

\section{Reasons for Nonuse}

To better understand the role of supply and demand factors in women's choice of contraceptive methods, I examined the reasons for not practicing family planning given

* depart from the 2002-2003 IDHS by including lactational amenorrhea among the traditional methods. Because the method by definition covers only the first six months after childbirth and requires the mother to be amenorrheic and to breastfeed exclusively, women who do not switch to another method when these conditions do not apply have a high risk of unwanted pregnancy. In a country like Indonesia, where about $70 \%$ of all 2-5-month-old children receive nutritional supplements, breastfeeding provides little protection. Only $0.1 \%$ of married women use it as a contraceptive method.
TABLE 2. Percentage distribution of currently married women using contraceptives, by type of method, according to socioeconomic status

\begin{tabular}{lcccc} 
Type & All & $\begin{array}{l}\text { Extremely } \\
\text { poor }\end{array}$ & $\begin{array}{l}\text { Moderately } \\
\text { poor }\end{array}$ & $\begin{array}{l}\text { Better } \\
\text { off }\end{array}$ \\
\hline Modern & $(\mathrm{N}=15,335)$ & $(\mathrm{N}=2,003)$ & $(\mathrm{N}=1,669)$ & $(\mathrm{N}=11,663)$ \\
Short-term hormonal & 72.7 & 76.1 & 74.5 & 72.1 \\
Long-term & 25.8 & 23.4 & 25.4 & 26.1 \\
Barrier & 1.5 & 0.5 & 0.1 & 1.8 \\
Design-based F=3.1, $p<.05$ & & & & \\
Any & & & & \\
Short-term hormonal & $(\mathrm{N}=16,458)$ & $(\mathrm{N}=2,152)$ & $(\mathrm{N}=1,766)$ & $(\mathrm{N}=12,540)$ \\
Long-term & 68.2 & 67.9 & 70.5 & 67.9 \\
Barrier & 24.2 & 20.9 & 24.0 & 24.6 \\
Traditional & 1.4 & 0.5 & 0.1 & 1.7 \\
Design-based F=3.3, $p<.05$ & 6.2 & 10.8 & 5.3 & 5.9 \\
& & & & \\
Total & & 100.0 & 100.0 & 100.0 \\
\hline
\end{tabular}

Notes: Short-term hormonal methods are the pill and injectables. Long-term methods include the IUD, the implant and sterilization. Barrier methods include condoms and vaginal methods. Traditional methods include withdrawal, periodic abstinence and the lactational amenorrhea method.

by married women who wanted to space or limit births. About $40 \%$ of women, both poor and better off, cited reasons related to fertility, which in most cases meant that women did not consider themselves to be at risk of pregnancy because they did not have sex regularly, were menopausal, believed themselves to be infecund or were experiencing postpartum amenorrhea (Table 3). About 25\% of women in all socioeconomic categories reported health reasons, usually concerns or fears about possible side effects of contraceptives.

The next most cited group of reasons involved knowledge and attitudes, such as opposition to family planning by the respondent or her spouse, religious prohibitions and lack of knowledge about contraceptive methods. Twelve percent of extremely poor and $9 \%$ of moderately poor women cited these reasons, compared with $6 \%$ of better-off women. Costrelated reasons were mentioned by $6 \%$ of extremely poor women, $10 \%$ of moderately poor women and $4 \%$ of betteroff women. The least-cited reason was lack of access to contraceptives: Overall, fewer than 1\% cited this as the reason for not using family planning, and the differences among the three socioeconomic categories were not significant.

TABLE 3. Among currently married women who want to space or limit births but are not using a contraceptive method, the percentage reporting specific reasons for not using contraceptives, according to socioeconomic status

\begin{tabular}{llllc} 
Reason & $\begin{array}{l}\text { All } \\
(\mathrm{N}=5,356)\end{array}$ & $\begin{array}{l}\text { Extremely } \\
\text { poor } \\
(\mathrm{N}=1,216)\end{array}$ & $\begin{array}{l}\text { Moderately } \\
\text { poor } \\
(\mathrm{N}=673)\end{array}$ & $\begin{array}{l}\text { Better } \\
\text { off } \\
(\mathrm{N}=3,467)\end{array}$ \\
\hline Fertility-related & 43.2 & 37.6 & $46.5 \dagger$ & $43.7 \dagger$ \\
Health-related & 25.6 & 23.6 & 21.0 & $26.7 \neq$ \\
Related to knowledge and attitudes & 6.7 & 11.8 & 8.8 & $5.5+, \neq$ \\
Cost-related & 5.1 & 6.3 & 9.7 & $4.2 \neq$ \\
Access-related & 0.8 & 1.4 & 1.6 & 0.5 \\
Other & 28.1 & 28.6 & 28.4 & 28.0 \\
\hline
\end{tabular}

†Differs significantly from the extremely poor at $\mathrm{p} \leq .01$. $\neq$ Differs significantly from the moderately poor at $\mathrm{p} \leq .01$ Notes: Fertility-related reasons include infecundity or sterility, postpartum amenorrhea, not having sex and having reached menopause. Health-related reasons include health concerns and fear of side effects. Reasons related to knowledge and attitudes include opposition to family planning by the respondent or her spouse, religious prohibitions and lack of knowledge about methods. Respondents could give more than one reason. 
TABLE 4. Odds ratios from multivariate logistic regression analysis assessing the association between use of modern contraceptive methods by currently married women and selected characteristics

Characteristic

Odds ratio

$(\mathrm{N}=27,615)$

Socioeconomic status

Extremely poor (ref)

Moderately poo

Better off

1.00

$1.37^{* * *}$

Education

$<$ complete primary (ref) $\quad 1.00$

$\geq$ complete primary $\quad 1.09$

Residence

Urban (ref)

Rural

1.00

Age

$15-34$ (ref)

35-49

1.00

$0.60 * *$

No. of living children

$\leq 2$ (ref)

3-4

$\geq 5$

Ideal no. of children

Nonnumeric response (ref) $\quad 1.00$

$\leq 2$

$\geq 3$

District's mean ideal no. of childrent

Above national median (ref)

Below national median

1.00

$1.45^{* * *}$

Exposure to family planning messages in preceding 6 mos.

Not exposed (ref)

Exposed to a single source

1.00

Exposed to multiple sources

$1.29 * * *$

${ }^{* * *} \mathrm{p} \leq .001$. $†$ Not including the respondent. Note: ref=reference group

\section{Factors Associated with Modern Method Use}

Multivariate logistic regression analysis found significant positive associations between socioeconomic status and contraceptive use (Table 4). After controlling for demographic and cultural factors, moderately poor women and better-off women had higher odds of using modern contraceptives than did extremely poor women (odds ratios, 1.4 and 1.6, respectively). The odds were also higher among rural women than among their urban counterparts (1.2), whereas women aged 35-49 had lower odds than did younger women (0.6).

As one would expect, the number of living children strongly influenced women's contraceptive use. Women with three or four children had higher odds of using modern contraceptives than did women with two or fewer children (odds ratio, 2.2). The odds for women with five or more children were not as high (1.4), presumably because they were older, less fertile or more likely to have secondary sterility.

One attitudinal factor showed a stronger association with contraceptive use than did socioeconomic status: Compared with women who said the ideal number of children was up to God or their husband, or gave some other nonnumeric answer, those who considered two or fewer children ideal had higher odds of using contraceptives (odds ratio, 2.0), as did women whose ideal was three or more children (1.4).

The ideal number of children in the respondents' social environment showed a strong association with contraceptive use. As explained earlier, the median value for all districts' mean ideal number of children was 2.84 . Women residing in districts where the mean ideal number was less than 2.84 were more likely to use contraceptives than were women in districts whose mean was more than this (odds ratio, 1.5). Exposure to family planning messages was also positively associated with contraceptive use. Women who had been exposed to family planning messages from a single source or multiple sources had higher odds of using modern contraceptives than did women who had not been exposed to such messages ( 1.3 and 1.5, respectively).

Thus, some cultural, attitudinal and knowledge factors had associations with contraceptive use that were as strong as or stronger than those found for socioeconomic status, suggesting that their impact on the decision to use contraceptives may sometimes be more important than the ability to pay for contraceptives.

\section{Attitudes Toward Childbearing and Family Planning}

Given the importance of attitudes in shaping a woman's decision to use or not to use contraceptives, I examined attitudes toward childbearing and family planning among the three socioeconomic categories of women.

My results corroborated the nearly universal finding in developing countries that the poorer women are, the more children they want. The mean ideal number of children was 3.4 for extremely poor women, 3.0 for moderately poor women and 2.8 for better-off women (Table 5). Among women with two or more living children, $28 \%$ of the extremely poor women wanted another child, compared with $24 \%$ of moderately poor and $18 \%$ of better-off women. Extremely poor women, who had significantly lower contraceptive use and higher unmet need than other women (see Table 1), were less likely to report that their last or current pregnancy was mistimed or unwanted than were women of higher socioeconomic status (13\% vs. 16\%-17\%)-an apparent paradox. Then again, one would expect women who prefer larger families to be less likely to have an unwanted pregnancy even when reported to have an unmet need for family planning

Compared with better-off women, poor women were less likely to approve of family planning (87-91\% vs. 93\%) and were also less likely to believe that their spouses approved (80-87\% vs. 91\%). Moreover, the extremely poor women were less likely to approve than the moderately poor women, and were less likely to believe that their spouses approved.

Because spousal communication is an important precursor to the adoption of family planning services, I calculated, among currently married women younger than 40 who did not use contraceptives, the proportion who had discussed family planning with their husbands during the 
six months preceding the survey.* As expected, women's socioeconomic status was related to whether they had talked about family planning with their spouses: Better-off women were significantly more likely than extremely or moderately poor women to have talked to their husbands about this topic ( $52 \%$ vs. $42-46 \%)$.

\section{Sources of Contraceptive Methods}

Contrary to the common perception among program managers and policymakers, not all poor women depend solely on the public sector to procure their contraceptives. A greater proportion of extremely poor women (39\%) than of moderately poor and better-off women do use the public sector (35\% and 26\%, respectively-Table 6). However, substantial proportions of poor women-37\% of the extremely poor and $46 \%$ of the moderately poor-get their contraceptives from private midwives. Extremely and moderately poor women rely less on other private sources than do better-off women ( $6 \%$ each vs. $18 \%$ ), whereas they depend on nongovernmental health posts and family planning posts, as well as informal sources, to a greater extent (13\%-18\% vs. $8 \%)$.

Many poor women can purchase contraceptives from the private sector in Indonesia because private midwives and NGOs offer fees that either match or are only slightly higher than public-sector fees. Private midwives, who as a group have become the country's major source of contraceptive supplies, generally charge reasonable fees; moreover, they commonly charge less to those who cannot afford their full fee. According to a survey of members of the Indonesian Midwife Association (Ikatan Bidan Indonesia), $76 \%$ of private midwives have a flexible fee structure, with an average discount of $30 \%$; one-third of those offering discounts will reduce their fees by $45 \%$ or more for needy clients. ${ }^{17}$

Flexible fee schedules are also common among NGOrun health facilities, particularly those associated with Islam. An assessment of a selected number of health facilities associated with Muslimat and Muhammadyah, two of the largest faith-based organizations in Indonesia, found that 98 out of the 100 surveyed facilities had policies that allowed low-income clients to pay lower fees. ${ }^{18}$

\section{Costs of Contraceptives}

To assess the cost of contraceptives, I looked at two variables: the proportion of users who obtained them for free, and the cost of supplies for paying users. For these calculations, I grouped extremely poor and moderately poor women; there were no significant differences between the two groups, and combining them provided adequate numbers for analysis of the source and contraceptive categories. As Table 7 (page 112) shows, short-term hormonal methods were low-priced,

*I excluded women aged 40-49 from the analysis; because they are at or near the end of their reproductive lives, many had little need to discuss family planning with their spouses. In this sample, women in this age-group contributed less than $5 \%$ of total fertility.

tThe average rate of exchange during the time of the survey (October 2002-April 2003) was 8,926 rupiah to US\$1.00.
TABLE 5. Selected indicators of fertility preferences and attitudes toward family planning among ever-married women aged 15-49, according to socioeconomic status

\begin{tabular}{|c|c|c|c|c|c|}
\hline Indicator & N & All & $\begin{array}{l}\text { Extremely } \\
\text { poor }\end{array}$ & $\begin{array}{l}\text { Moderately } \\
\text { poor }\end{array}$ & $\begin{array}{l}\text { Better } \\
\text { off }\end{array}$ \\
\hline Mean ideal no. of children§ & 25,300 & 2.9 & 3.4 & $3.0 \dagger$ & $2.8+, \neq$ \\
\hline$\%$ with $\geq 2$ children who want another child & 18,909 & 19.6 & 28.0 & $24.0+$ & $18.0+, \neq$ \\
\hline $\begin{array}{l}\% \text { with } \geq 2 \text { children who do not want } \\
\text { another child }\end{array}$ & 18,909 & 69.0 & 61.4 & $65.7 \dagger$ & $70.4+, \neq$ \\
\hline $\begin{array}{l}\% \text { whose last pregnancy was mistimed } \\
\text { or unwanted }+\dagger\end{array}$ & 14,354 & 16.3 & 13.1 & $15.7 \dagger$ & $17.2 \dagger$ \\
\hline$\%$ who approve of family planning & 29,457 & 92.5 & 87.2 & $91.0+$ & $93.4+, \neq$ \\
\hline $\begin{array}{l}\% \text { who believe their spouse approves of } \\
\text { family planning }\end{array}$ & 27,727 & 89.2 & 80.4 & $86.8 \dagger$ & $90.6+, \neq$ \\
\hline $\begin{array}{l}\% \text { of nonusers aged }<40 \text { who have discussed } \\
\text { family planning with their spousełキ }\end{array}$ & 8,220 & 49.9 & 41.7 & 46.2 & $51.8+, \neq$ \\
\hline
\end{tabular}

tDiffers significantly from the extremely poor at $\mathrm{p} \leq .05$. $\neq$ Differs significantly from the moderately poor at $\mathrm{p} \leq .05$. $\S$ Women who gave nonnumeric answers were excluded from the calculation. t+Includes only women who were pregnant at the time of the survey or who had had at least one live birth during the preceding five years. Women with an unwanted pregnancy were those who declared that their current pregnancy or their last child born during the preceding five years was not wanted. Women with a mistimed pregnancy were those who declared they would have preferred to wait two or more years before getting pregnant. ‡¥Includes only currently married women who had discussed family planning with their spouses during the preceding six months.

but very few users obtained them free of charge; long-term methods were relatively expensive, but a substantial proportion of users obtained them without charge.

Among poor women using a short-term hormonal method, only 3\% obtained it at no cost; those who paid were charged an average of US\$0.93. ${ }^{\dagger}$ The average monthly cost of food for low-income households was US\$21.30 in 2002, 19 so the amount a poor woman would have paid for a shortterm method represented slightly less than $5 \%$ of her monthly food budget. Even in the public sector, where contraceptives are offered at subsidized prices, only $7 \%$ of poor women obtained short-term hormonal methods for free. More important, the poor who bought these contraceptives in the public sector paid about as much as they would have if they had bought them elsewhere. It appears that public facilities are losing their former "competitive advantage" as a supplier of short-term methods, which explains why users have gradually shifted from the public to the private sector in recent years.

For users of long-term methods-the IUD, the implant and sterilization-the average cost for those who paid was

\begin{tabular}{|c|c|c|c|c|}
\hline Source & $\begin{array}{l}\text { All } \\
(N=15,327)\end{array}$ & $\begin{array}{l}\text { Extremely } \\
\text { poor } \\
(\mathrm{N}=2,002)\end{array}$ & $\begin{array}{l}\text { Moderately } \\
\text { poor } \\
(\mathrm{N}=1,668)\end{array}$ & $\begin{array}{l}\text { Better } \\
\text { off } \\
(\mathrm{N}=11,657)\end{array}$ \\
\hline Public sector & 27.8 & 39.2 & 35.0 & 26.0 \\
\hline Private midwives & 46.6 & 36.5 & 45.5 & 47.6 \\
\hline Other private sector & 16.1 & 6.0 & 6.1 & 18.2 \\
\hline Other & 9.5 & 18.3 & 13.4 & 8.3 \\
\hline $\begin{array}{l}\text { Total } \\
\text { Design-based } F=26.7, p<.001\end{array}$ & 100.0 & 100.0 & 100.0 & 100.0 \\
\hline
\end{tabular}

Notes: Public sector includes public hospitals, health centers, government-run clinics, and family planning field workers and mobile units. Private midwives are independent nurse-midwives and village midwives. The private sector includes pharmacies and medical sources such as doctors and private clinics. "Other" includes nongovernmental village delivery posts (Polindes), health posts (Posyandu) and family planning posts, as well as informal sources such as friends and relatives. 
TABLE 7. Mean cost of contraceptive methods (in US\$) and percentage of women who obtained them free, by source of last method, according to type of method and socioeconomic status

Source, cost and percentage

\begin{tabular}{|c|c|c|c|c|c|c|c|c|c|}
\hline \multirow{2}{*}{ percentage } & & \\
\hline & $\begin{array}{l}\text { All } \\
(N=15,392)\end{array}$ & $\begin{array}{l}\text { Poor } \neq \\
(\mathrm{N}=3,682)\end{array}$ & $\begin{array}{l}\text { Better off } \\
(\mathrm{N}=11,710)\end{array}$ & $\begin{array}{l}\text { All } \\
(\mathrm{N}=11,043)\end{array}$ & $\begin{array}{l}\text { Poor‡ } \\
(\mathrm{N}=2,820)\end{array}$ & $\begin{array}{l}\text { Better off } \\
(\mathrm{N}=8,223)\end{array}$ & $\begin{array}{l}\text { All } \\
(\mathrm{N}=4,093)\end{array}$ & $\begin{array}{l}\text { Poor } \neq \\
(N=858)\end{array}$ & $\begin{array}{l}\text { Better off } \\
(\mathrm{N}=3,235)\end{array}$ \\
\hline \multicolumn{10}{|l|}{ Cost } \\
\hline All sources & $\$ 5.52$ & $\$ 1.59$ & $\$ 6.31^{* * *}$ & $\$ 0.98$ & $\$ 0.93$ & $\$ 0.99$ & $\$ 18.41$ & $\$ 3.57$ & $\$ 21.21^{* * *}$ \\
\hline Public sector & 7.10 & 1.81 & $8.61^{* * *}$ & 0.92 & 0.94 & 0.92 & 13.48 & 2.88 & $16.14^{* * *}$ \\
\hline Private midwives & 1.49 & 1.39 & 1.51 & 1.08 & 1.04 & 1.09 & 4.57 & 4.01 & 4.67 \\
\hline Other private sector & 17.28 & 3.69 & $18.20^{* * *}$ & 0.91 & 0.72 & $0.92^{* *}$ & 48.63 & $\mathrm{u}$ & 49.43 \\
\hline Other & 0.59 & 0.77 & $0.52^{* *}$ & 0.55 & 0.69 & $0.50^{*}$ & 0.85 & $\mathrm{u}$ & 0.70 \\
\hline \multicolumn{10}{|l|}{ Obtained free } \\
\hline All sources & 11.4 & 13.5 & $11.0^{* * *}$ & 2.7 & 3.4 & 2.6 & 35.8 & 44.7 & $34.1^{* * *}$ \\
\hline Public sector & 24.1 & 25.5 & 23.7 & 5.3 & 6.7 & 4.9 & 43.5 & 49.0 & $42.1^{* * *}$ \\
\hline Private midwives & 3.6 & 3.4 & 3.7 & 1.0 & 0.8 & 1.0 & 23.7 & 22.7 & 23.8 \\
\hline Other private sector & 9.7 & 7.9 & 9.8 & 4.0 & 1.4 & $4.2^{* *}$ & 19.8 & $\mathrm{u}$ & 19.1 \\
\hline Other & 15.3 & 14.2 & 15.7 & 5.4 & 6.1 & 5.1 & 70.9 & $\mathrm{u}$ & 75.5 \\
\hline
\end{tabular}

${ }^{*} \mathrm{p} \leq .05 .{ }^{* *} \mathrm{p} \leq .01 .{ }^{* * *} \mathrm{p} \leq .001$. Includes barrier methods as well as short-term hormonal and long-term methods. $\neq$ Combines extremely poor and moderately poor women to obtain enough cases for analysis. Notes: $\mathrm{u}=$ unavailable, because there were fewer than 100 cases. At the time the data were collected, US\$1.00 $=8,926$ rupiah.

US $\$ 18.41$. In contrast to the case with short-term hormonal methods, $45 \%$ of poor users of long-term methods were able to obtain them free of charge; even among those who obtained these methods from private midwives, $23 \%$ received the method at no cost.

In brief, the public sector offers little advantage over the private sector for poor women who use short-term hormonal methods. However, it represents a major advantage for users of long-term methods-the greater possibility of obtaining the method free of charge or at reduced cost.

\section{DISCUSSION}

Poverty is a multidimensional socioeconomic condition, and an attempt to define it using a multipurpose data set such as the IDHS is bound to yield only an approximate representation. Despite this imprecision in defining poverty, however, I believe this article provides a new perspective on contraceptive use among the Indonesian poor. There are significant differences in the use of modern contraceptives by extremely poor, moderately poor and betteroff women.

Poor couples-less educated and less exposed to media than others-are likely to lag behind better-off couples in adopting family planning and a small-family ethos. Poor women want larger families, are less approving of family planning and tend to use basic health services less frequently than do women of higher socioeconomic status. To place the current Indonesian situation in perspective, the CPR among the extremely poor today is similar to the CPR for the general Indonesian population 15 years ago; for the moderately poor, the lag is about eight years. It appears, therefore, that significant barriers to the adoption of modern contraceptives still exist for poor women in Indonesian society.

*Health concerns are considered to be an attitudinal factor, even though such concerns are sometimes medically grounded. However, women who have such concerns are likely to be ambivalent about using contraceptives, regardless of their cost or their accessibility.
Contrary to commonly held assumptions, particularly among policymakers and program managers in family planning, the findings of this study suggest that attitudinal factors-such as desire for more children, opposition to family planning and concerns about the health effects of contraceptive methods*-are at least as important as cost and access in deterring poor women from using contraceptives. In the 2002-2003 IDHS, 30-35\% of moderately or extremely poor women who wanted to space or limit births but were not using contraceptives cited attitudinal factors, whereas $8-11 \%$ mentioned reasons related to cost or access. Moreover, if the reasons for not using modern contraceptives were mainly related to monetary constraints, one would expect the strongest association in the multivariate analysis to be between socioeconomic status and contraceptive use, but that was not the case. Instead, the strongest associations were with variables related to ideal and actual family size.

One possible explanation is that the majority of Indonesian women have become accustomed to paying for contraceptives. According to IDHS data not shown in this article, $95 \%$ of the poorest women paid for their short-term hormonal methods and 60\% paid for their long-term methods. Furthermore, poor women paid nearly as much as did better-off women for short-term hormonal methods.

These results suggest that a broad-scale intervention aimed at increasing the CPR among the poor by offering contraceptives at subsidized prices would be only partially successful. To be effective, the principal objectives of such an intervention should include lowering cultural and attitudinal barriers and increasing contraceptive demand.

\section{REFERENCES}

1. State Ministry for Population and National Family Planning Coordinating Board (BKKBN), 25 Years of Family Planning Movement, Jakarta, Indonesia: BKKBN, 1995; and BKKBN, Basic Information: Family Planning Movement, Prosperous Family Development, Jakarta, Indonesia: BKKBN, 1996.

2. Central Bureau of Statistics (CBS), BKKBN, Ministry of Health and Macro International, Indonesia Demographic and Health Survey 1991, 
Columbia, MD, USA: CBS and Macro International, 1992; and Badan Pusat Statistik (BPS) and ORC Macro, Indonesia Demographic and Health Survey 2002-2003, Calverton, MD, USA: BPS and ORC Macro, 2003.

3. Robey B, Piotrow PT and Salter C, Family planning lessons and challenges: making programs work, Population Reports, 1994, Series J, No. 40.

4. Jensen ER et al., Contraceptive pricing and prevalence: family planning self-sufficiency in Indonesia, paper presented at the annual meeting of the Population Association of America, Cincinnati, OH, USA, Apr. $1-3,1993$

5. Stalker PA, Beyond Krismon: The Social Legacy of Indonesia's Financial Crisis, Jakarta, Indonesia: United Nations Children's Fund, 2000.

6. Frankenberg E et al., Contraceptive Use in a Changing Service Environment: Evidence from the First Year of Indonesia's Economic Crisis, Chapel Hill, NC, USA: Carolina Population Center, 2001.

7. Molyneaux J, The Evolution of Contraceptive Pricing in Indonesia: A Final Report to the Policy Project, Washington, DC: Futures Group International, 2000.

8. CBS and Macro International, 1992, op. cit. (see reference 2); and BPS and ORC Macro, 2003, op. cit. (see reference 2).

9. Ravenholt RT and Chao J, Availability of family planning services: the key to rapid fertility reduction, Family Planning Perspectives, 1974 , 6(4):217-223; and Finkle CT, Hutchings J and Vail J, Contraceptive security: toward a framework for a global assessment, in: Meeting the Challenge: Securing Contraceptive Supplies, Washington, DC: Population Action International, 2001

10. Feyisetan B and Casterline JB, Fertility Preferences and Contraceptive Change in Developing Countries, Research Division Working Papers, New York: Population Council, 1999, No. 130; and Lockwood M, Institutional and Cultural Determinants of Demand for Reproductive Health Services in Sub-Saharan Africa: A Review and Implications for Research, Research Paper, London: London School of Hygiene \& Tropical Medicine, Centre for Population Studies, 2000, No. 00-1.

11. Gwatkin DR et al., Socio-Economic Differences in Health, Nutrition and Population in Indonesia, monograph prepared for the HNP/Poverty Thematic Group of The World Bank, Washington, DC: World Bank, 2000 .

12. Deaton A and Muellbauer J, Economics and Consumer Behavior, London: Cambridge University Press, 1980

13. Retherford RD and Mishra V, Media exposure increases contraceptive use, National Family Health Survey Bulletin, 1997, 7:1-4; Westoff CF, Mass communications and fertility, in: Leete R, Dynamics of Values in Fertility Change, Oxford, UK: Oxford University Press, 1999, pp. 237-251; and Islam MM and Hasan AH, Mass media exposure and its impact on family planning in Bangladesh, Journal of Biosocial Science, 2000, 32(4): 513-526.

14. Fu H et al., Contraceptive failure rates: new estimates from the 1995 National Survey of Family Growth, Family Planning Perspectives, 1999 , 31(2):52-63; and Health Learning Systems, Contraceptive failure and discontinuation, Dialogues in Contraception, 1998, Vol. 5, No. 6, <http:// www.dialoguesonline.com>, accessed July 15, 2001

15. BPS and ORC Macro, 2003, op. cit. (see reference 2).

16. Menayang V, Understanding the constraints and supports to the family planning practices of the poor, unpublished report, Johns Hopkins University (JHU), Center for Communication Programs, Indonesia Field Office, Jakarta, Indonesia, 2004.

17. JHU, Private midwives survey: September 2003, unpublished report, JHU, Center for Communication Programs, Indonesia Field Office, Jakarta, Indonesia, 2004

18. JHU, Muslimat and Muhammadyah membership inventory survey, unpublished report, JHU, Center for Communication Programs, Indonesia Field Office, Jakarta, Indonesia, 2003.

19. BPS, Survei Sosial Ekonomi Nasional 2002, Jakarta, Indonesia: BPS, 2002.

\section{RESUMEN}

Contexto: Durante los últimos 30 años en Indonesia hubo un aumento dramático del uso de anticonceptivos y una disminución de la fecundidad igualmente notoria. No obstante, recientes reducciones del financiamiento de los servicios de planificación familiar, la descentralización del programa y el papel decreciente del sector público como proveedor de estos servicios pueden conducir a la reducción del uso de anticonceptivos entre las mujeres pobres.

Métodos: Los datos para este análisis fueron obtenidos de la Encuesta Demográfica y de Salud de Indonesia realizada en 2002-2003. Se utilizaron técnicas de análisis bivariado para comparar el uso general de anticonceptivos, el uso de métodos especificos, la fuente de suministros y las razones para no usar anticonceptivos entre el grupo de mujeres pobres y el de mujeres en mejores condiciones económicas. Mediante análisis de regresión con múltiples variables, se evaluó la relación entre uso de anticonceptivos modernos y ciertas características sociales, demográficas y de actitud.

Resultados: En comparación con las mujeres moderada o extremadamente pobres, las mujeres de mejores condiciones económicas deseaban un número significativamente menor de hijos (2,8 contra 3,0-3,4), eran más proclives a aprobar la planificación familiar (93\% contra 87-91\%) y también eran más proclives a creer que sus cónyuges aprobaban esta práctica (91\% contra 80-87\%). Las mujeres de mejores condiciones económicas y aquellas moderadamente pobres tenían mayores probabilidades de usar anticonceptivos modernos que las mujeres extremadamente pobres (razones de momios de 1,6 y 1,4, respectivamente). En comparación con las mujeres que ofrecieron respuestas no numéricas en cuanto al tamaño ideal de la familia, aquellas que deseaban tener dos o menos hijos presentaban mayores probabilidades de estar usando un método anticonceptivo $(2,0)$. Las probabilidades eran también más elevadas entre las mujeres que residian en un distrito en el que el número ideal de hijos era inferior a la mediana nacional (razón de momios, 1,5).

Conclusión: Los esfuerzos del gobierno para incrementar el uso de anticonceptivos entre las mujeres pobres deben concentrar la atención en cambiar las actitudes de este grupo en cuanto al tamaño de la familia y la planificación familiar.

\section{RÉSUMÉ}

Contexte: Ces 30 dernières années, l'Indonésie a enregistré une hausse spectaculaire de la pratique contraceptive et un déclin tout aussi remarquable de la fécondité. Les récentes coupes budgétaires du planning familial, la décentralisation des programmes et le moindre rôle du secteur public dans la prestation des services risquent toutefois d'affaiblir la pratique contraceptive des femmes pauvres.

Méthodes: Les données proviennent de l'EDS indonésienne de 2002-2003. La pratique contraceptive générale, le recours à certaines méthodes, les sources d'approvisionnement et les raisons de non pratique des femmes pauvres par rapport à celles mieux loties ont été comparées par méthodes bivariées. L'association entre la pratique d'une méthode moderne et certaines caractéristiques sociodémographiques et d'attitudes a été éva- 
luée par régression multivariée.

Résultats: Les femmes mieux loties désiraient significativement moins d'enfants que celles moyennement ou extrêmement pauvres (2,8 par rapport à 3,0-3,4); elles étaient plus susceptibles d'approuver le planning familial et de penser que leur époux l'approuvait (93\% et $91 \%$ par rapport à $87-91 \%$ et 80-87\%, respectivement). Les femmes mieux loties et moyennement pauvres étaient plus susceptibles de pratiquer la contraception moderne que celles extrêmement pauvres (rapport de probabilités, 1,6 et 1,4, respectivement). Par rapport aux femmes qui avaient donné une réponse non numérique, celles qui désiraient deux enfants ou moins étaient plus susceptibles de pratiquer une méthode moderne (2,0). Cette probabilité était également supérieure parmi les résidentes d'un district caractérisé par un nombre idéal moyen d'enfants inférieur à la médiane nationale $(1,5)$.

Conclusion: Les efforts gouvernementaux d'accroissement de la pratique contraceptive des femmes pauvres doivent se concentrer sur le changement des attitudes à l'égard des familles moins nombreuses et du planning familial.

\section{Acknowledgments}

This research was supported by the U.S. Agency for International Development/Indonesia (cooperative agreement 497-A-00-00000048-00). The author thanks Jane Bertrand, Gary Lewis and Monica Kerrigan for valuable comments on early drafts of this article.

Author contact: jschoema@jhuccp.org 